
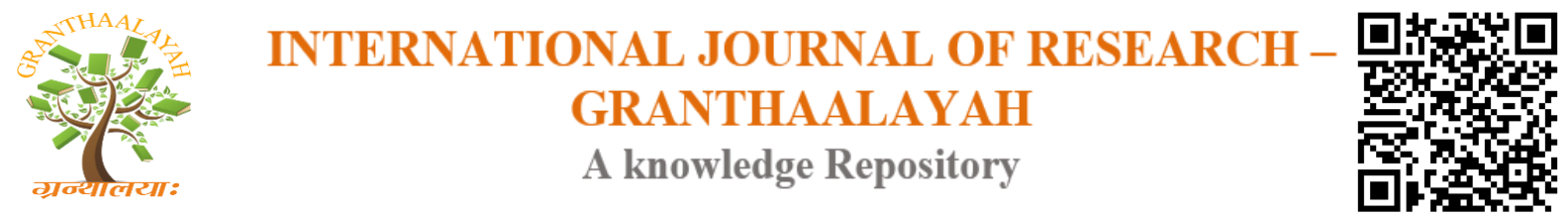

Science

\title{
THE IMPACTS OF CLIMATE CHANGE ON LIVESTOCK PRODUCTION AND PRODUCTIVITIES IN DEVELOPING COUNTRIES: A REVIEW
}

\author{
Getachew Bekele Fereja ${ }^{1}$ \\ ${ }^{* 1}$ Department of Animal Science, College of Agriculture and Natural Resource, Gambella \\ University, PO Box 126, Gambella, ETHIOPIA
}

DOI: https://doi.org/10.29121/granthaalayah.v4.i8.2016.2578

\section{ABSTRACT}

It is true that most proportions of Africans livestock production and productivities are declined when the climate condition is not comfortable. Therefore this review was conducted to show the impacts of climate change on livestock production and productivities. The climate change especially global warming may highly influence production performance of farm animals throughout the world. While there has been occasional mention, in the global discussion on climate change there has generally been a dearth of attention paid to the animal production and productivities impacts of the proposed abatement options and some of the suggested livestock management approaches would have severe and wide-ranging impacts on the animal's products. This is on the background that the impact of climate change on crops is well known, much less is known about the impact of climate change on livestock. Unfortunately, livestock production and productivities assumes an overriding emphasis as one of the core sectors to solve the current food challenges and bringing future food sustainability in developing countries. Out of all the factors influencing livestock production, climate, and location are undoubtedly the most significant. Climate change will have far-reaching consequences for animal production, especially in vulnerable parts of the world where it is vital for nutrition and livelihoods. The impact of climate change can heighten the vulnerability of livestock systems and exacerbate existing stresses upon them, such as drought. Parasites and diseases are among the most severe factors that impact livestock production and productivity. Animal diseases have great impact on food supplies, trade and commerce, and human health globally. Animal genetic diversity is critical for food security and rural development. It allows farmers to select stocks or develop new breeds in response to changing conditions.

Keywords:

impact, livestock, climate, production.

Cite This Article: Getachew Bekele Fereja, "THE IMPACTS OF CLIMATE CHANGE ON LIVESTOCK PRODUCTION AND PRODUCTIVITIES IN DEVELOPING COUNTRIES: A REVIEW” International Journal of Research - Granthaalayah, Vol. 4, No. 8 (2016): 181-187. 


\section{INTRODUCTION}

Agriculture is the back bone of most African countries economy. The agricultural sector is the largest domestic producer across the continent and employs about $70 \%$ to $90 \%$ of the total labor force. Moreover this sector supplies up to $50 \%$ of household food demand and up to $50 \%$ of their income. In addition most of the income generated by livestock rearing such as dairy cattle, beef cattle, sheep, goat and chickens. In most rural communities livestock is the only asset of the poor. But it is highly susceptible to climate variability extremes. The effect of climate change is anticipated to heighten the susceptibility of livestock system and reinforce the existing factors that are affecting livestock production systems. Therefore the objective of this review is to review the impact of climate change on livestock production and productivities.

Climate change is actually the most important environmental issue of any time. With severe and widespread destructive effects, warming of the planet threatens ecological systems, peoples' livelihoods, and species survival. Animal production under agriculture is an important source of greenhouse gas (GHG) emissions and has been implicated as a serious contributor to climate change. The climate impacts anticipated for developing country are similar to those being experienced around the world: general warming (day and night temperatures all year round); changes in rainfall timing and quantities; changes in seasons (longer summers); increased climate variability (e.g. floods, droughts and heat waves); higher sea-levels; and increasing frequency and intensity of extreme weather events (IPPC, 2007).

While there has been occasional mention, in the global discussion on climate change there has generally been a dearth of attention paid to the animal production and productivities impacts of the proposed abatement options, and some of the suggested livestock management approaches would have severe and wide-ranging impacts on the animal's products. This is on the background that the impact of climate change on crops is well known, much less is known about the impact of climate change on livestock. Unfortunately, livestock production and productivities assumes an overriding emphasis as one of the core sectors to solve the current food challenges and bringing future food sustainability in developing countries. The intergovernmental Panel on Climate Change (IPCC, 2007) is now overwhelmingly convinced that climate change is real, that it will become worse, and that the poorest regions and small scale famers will be the worst affected. The impact of climate change will call for a balanced type of animal which can produce in stressful environment as a result the utilization of adaptive livestock genotypes which may sustain production and productivities in this regard. Climate change taking the centre stage the merit of indigenous livestock apart from their ability to adapt to stressful environment are a valuable asset to the smallholder farmers as they provide their basic needs.

On the other hand, it is believed that livestock production and productivities will be one of the most susceptible sectors to climate change due to changes in hydrological cycle, temperature balance and rainfall patterns which have a negative impact on livestock production and productivity (Mwiturubani, 2010). The direct impacts of air temperature, humidity and wind speed capable of influencing growth rate, milk production, wool production and reproduction have been reported by (Houghton, 2001) and (Rust and Rust (2013). 


\section{MEASURING THE IMPACTS OF CLIMATE CHANGE ON ANIMAL PRODUCTION AND PRODUCTIVIES}

All stocks however, showed varying degrees of vulnerability to diseases associated with climate variability. Cattle, Sheep Goats Equine and Camels recorded the maximum vulnerability for diseases. For floods, owners noted that large animals had some advantage, due to their ability to float/swim in water channels, as it is by their high adaptability. All other stocks are extremely vulnerable. During review time which was noted that during at the time of floods, camels and small ruminants are almost totally immobile and thus, cannot access pasture areas for their feeds. In general this contributed highly to animal losses. In the face of climate challenges, adaptation of different livestock species to tropical conditions becomes highly imperative. A report by the FAO's Committee on Genetic Resources for Food and Agriculture (CGRFA, 2009) noted that the management of animals under natural selection by pastoralists in marginal areas plays an essential role in their adaptation and fitness in such environments.

\section{THE IMPACTS OF CLIMATE CHANGE ON LIVESTOCK PRODUCTION AND PRODUCTIVITIES}

The direct effects of air temperature, humidity and wind speed capable of influencing growth rate, milk production, wool production and reproduction have been reported by (Houghton, 2001, Rust, 2013). The quantity and quality of livestock feed stuffs such as pasture and forage can be indirectly affected by climate change (McCarthy et al., 2001) significantly influencing farmers livestock selection choices.

Also, the severity and distribution of livestock diseases and parasites is conditioned by climate change (Thornton and Herrero, 2008). The challenges of climate change will call for a balanced type of animal which can produce in stressful environment as a result the utilization of adaptive livestock genotypes which may sustain production in this regard. Climate change taking the centre stage the merit of indigenous livestock apart from their ability to adapt to stressful environment are a valuable asset to the smallholder farmers as they provide their basic needs.

\section{IMPACTS OF CLIMATE CHANGE ON ANIMAL PRODUCTION}

Climate change will have far-reaching consequences for animal production, especially in vulnerable parts of the world where it is vital for nutrition and livelihoods. The impact of climate change can heighten the vulnerability of livestock systems and exacerbate existing stresses upon them, such as drought. Ensuring good animal welfare will be paramount to addressing these challenges; breeds suited to the local environment are often more robust and resilient than industrially farmed breeds (www.fao.org/docrep/meeting/022/mb386e.pdf (accessed 28 November 2011)). There is a range of thermal conditions within which animals are able to maintain a relatively stable body temperature by means of behavioral and physiological means (Champaign, IL 61820, pp: 609-618). Heat stress results from the animal's inability to dissipate sufficient heat to maintain homoeothermic. 


\section{IMPACT OF CLIMATE CHANGE ON ANIMAL FEED RESOURCES}

Out of all the factors influencing livestock production, climate, and location are undoubtedly the most significant. In fact, climatology characteristics such as ambient temperature and rainfall patterns have great influence on pasture and food resources availability cycle throughout the year among animal populations. As discussed before, the rain pattern during the year strongly conditions livestock production systems through pasture development and disease and parasites outbreaks, therefore influencing animal production systems, productivity. Tropical and Mediterranean climates are characterized by the existence of a season of varied duration, when rainfall is scanty or non-prevalent. Such season is termed dry season in the tropics and summer in Mediterranean climates. During rainy season pastures are available in higher quantities and show good nutritional quality whereas dry season's pastures have poor nutritional quality with high fiber and low protein contents (Butterworth 1984), which often results in declining the animal production.

\section{IMPACT OF DISEASES AND PARASITES ON LIVESTOCK PRODUCTIVITY DUE TO CLIMATE CHANGE}

Parasites and diseases are among the most severe factors that impact livestock production and productivity. Animal diseases have great impact on food supplies, trade and commerce, and human health globally. The last few decades have seen a general reduction in the burden of livestock diseases. Such reduction is the direct result of the availability and effectiveness of drugs and vaccines, as well as improvements in diagnostic technologies (Pearson 2006; Thornton 2010). Future disease trends are likely to be effectively managed by disease surveillance and control technologies.

At the same time, new diseases have emerged and will continue to spread by the international movement of animals and animal products, such as avian influenza. This disease has caused considerable global concern about the potential for a change in host species from poultry to man and an emerging global pandemic of human influenza (Murray 2006; Thornton 2010).

Livestock diseases can cause direct losses (deaths, stunting, reduced fertility, and changes in herd structure) and indirect losses (additional costs for drugs and vaccines, added labor costs and profit losses due to denied access to better markets and use of suboptimal production technology) in revenue (Rushton 2009). Large ruminants are generally regarded as the most important domestic livestock species in the world. The importance is demonstrated by the list of products they provide. In developed countries, their contributions are mainly restricted to commercial products such as meat and milk. In developing countries they are a source of food, particularly protein for human diets, and they provide income, employment, transport, can serve as a store of wealth, and provide draft power and organic fertilizer for crop production (Perry et al. 2005; Rushton 2009).

\section{IMPACT OF CLIMATE CHANGE ON ANIMAL GENETICS RESOURCE}

Animal genetic diversity is critical for food security and rural development. It allows farmers to select stocks or develop new breeds in response to changing conditions, including climate change, new or resurgent disease threats, new knowledge of human nutritional requirements, and 
changing market conditions or changing societal needs - all of which are largely unpredictable. What is predictable is increased future human demand for food. The effects will be most acute in developing countries, where the increase in demand is expected to be greatest, and occur at a rate faster than increases in production (FAO, 2003; 2006a), and where climate change is projected to have its greatest impact.

Most flows of genetic material occur among developed countries, most of which are without zoosanitary restrictions, and involve animals suited to high-input production systems (ValleZarate et al., 2006; Hiemstra et al., 2007). More than $90 \%$ of exports originate from developed countries, and the share of trade in genetic material from developed to developing countries increased from $20 \%$ in 1995 to 30\% in 2005 (Gollin et al., 2008). In many cases, the improved components of the high-input management systems needed to express the genetic potential of the high-output breeds have been transferred to developing countries. Industrial systems utilizing sophisticated technology and based on internationally sourced feed and animal genetics already produce $55 \%$ of pork, $68 \%$ of eggs and $74 \%$ of poultry meat globally (FAO, 2003; Steinfeld et al., 2006).

Climate change will affect the products and services provided by agricultural biodiversity. But this biodiversity has not yet been properly integrated into strategies for adaptation to and mitigation of climate change. Its role in the resilience of food systems still needs to be addressed. The Intergovernmental Panel on Climate Change (IPCC) report on biological diversity (Gitay et $a l ., 2002)$ and likewise the report of the Convention on Biological Diversity on climate change (CBD, 2009) contain little mention of agricultural biodiversity, and a recent literature review (Campbell et al., 2009) largely ignores livestock diversity. In a survey on threats to livestock diversity (FAO, 2009c), climate change was only mentioned as a minor factor in the context of extensive land-based production systems. The findings show that many stakeholders do not yet perceive climate change as a problem for the management and conservation of livestock biodiversity.

While substantial differences in thermal tolerance lie between species, there are also differences between breeds of a species. Ruminants generally have a higher degree of thermal tolerance than monogastric species, but species and breed environmental envelopes overlap. The ability to thermoregulate depends on complex interactions among anatomical and physiological factors. Factors such as properties of the skin and hair, sweating and respiration capacity, tissue insulation, the relationship between surface area per unit body weight or relative lung size, endocrinological profiles and metabolic heat production are known to influence heat loads, but the underlying physiological, behavioural or genetic mechanisms are largely unknown (Hall, 2004; McManus et al., 2008).

With increasing milk yield in dairy cattle, growth rates and leanness in pigs or poultry, metabolic heat production has increased and the capacity to tolerate elevated temperatures has declined (Zumbach et al., 2008; Dikmen \& Hansen, 2009). In the long term, single-trait selection for yields will therefore result in animals with lower heat tolerance. 


\section{CONCLUSION}

The review reported here addressed the very complex issue of impacts of climate change livestock production and productivities. Climate change could affect animal production and well-being, especially because of increases in air temperature. However, the knowledge of animal responses to heat stress during the hot months in several areas of the world, as well as during extreme heat events, may be used to evaluate the impacts of global change. However, farmers are not quite aware about the impacts global warming can produce in their operation.

At some point the people have experienced drought, and all this points to a changing climate. Livestock production is under threat from the changing climate. This is because the natural pastures which a majority of the livestock owners rely on for feeding their animals are deteriorating in quality and the amount of fodder available. In addition to that, water sources available are not reliable as they sometimes dry up due to high temperatures and shortage of rainfall. Livestock has been lost due to among other factors excessive heat, shortage of water and feed and unknown diseases.

Therefore, the following recommendations are forwarded for future action.

- Training about impact of climate change must be given for the livestock owners.

- The choice of representative climate stations for livestock enterprises, particularly in the arid and semi-arid regions must be considered.

- The recordation of additional inputs to pasture and livestock production, especially in climatically favorable zones must be applied.

\section{REFERENCES}

[1] Animal Genetic Resources Information 41, 65-74. assessment. Livestock Science 120 (3), 248-255. biodiversity. IPCC Technical Paper V. IPCC, Geneva, Switzerland. pp 85. Biol Sci 365:2853-2867.

[2] Brunner, S., Eickemeier, P., et al., Eds.; Cambridge University Press: New York, NY, USA, 2014; pp. 811-922.

[3] Bucklin, R.A., Hahn, G.L., Beede, D.K., Bray, D.R. 1992. Physical facilities for Butterworth MH (1984) Beef cattle nutrition and tropical pastures. Longman, London (England)

[4] Campbell A., Kapos V., Chenery A., Kahn, S.I., Rashid M., Scharlemann J.P.W. \& Dickson B. (2009). The. Carr DH (1984) The regulation of parotid and submandibular salivary secretion in sheep. Q J Exp Physiol 69:589-597.

[5] Challenges and Opportunities for Mitigation in the Agricultural Sector; United Nations, Climate Change 2014: Mitigation of Climate Change. Contribution of Working Group III to.

[6] D.A. Mwiturubani, Climate change and access to water resources in Lake Victoria basin; In; Mwiturubani Da and van Wyk JA (Ed) (2010) Climate change and natural resources conflicts in Africa, Institute for Security Studies, PO Box 1787, Brooklyn Square 0075, Pretoria, South Africa.

[7] Dikmen, S. \& Hansen P. J. (2009). Is the temperature-humidity index the best indicator of heat stress in drivers, trends. Revue scientific et technique Off. int. Epiz.25(2),505-516.

[8] FAO (2003) World agriculture: towards 2015/2030 - An FAO perspective. Bruinsma J. (Ed.), Earthscan. 
[9] FAO (2009a). Status and trends report on animal genetic resources -2008 . CGRFA/WGAnGR-5/09/Inf. 7.

[10] Food Agricultural Organisation (FAO), 2007. Climate Change: Climate Change Impacts, Adaptation and Vulnerability. IPCC WG II Forht Assessment Report.

[11] Framework Convention on Climate Change, Technical Paper. 2008. Available online: Genetic components of heat stress in finishing pigs: Genetic resources for the farming of the future. Blackwell, 264pp

[12] Harper, R.; House, J.; Jafari, M.; et al. Agriculture, forestry, and other land use (AFOLU). In Hiemstra, S.J., A.G. Drucker, M.W. Tvedt, N. Louwaars, J.K. Oldenbroek K. Awgichew, S. Abegazhttp://unfccc.int/resource/docs/2008/tp/08.pdf (accessed on 14 May 2015). IFAD, Rome.

[13] International Fund for Agricultural Development (IFAD)., 2011. Rural Poverty Report, final report,Gerber, P.J.; Steinfeld, H.; Henderson, B.; Mottet, A.; Opio, C.; Dijkman, J.; Falcucci, A.; Tempio, G. Tackling Climate Change through Livestock-A Global Assessment of Emissions and Mitigation Opportunities; Food and Agriculture Organization of the United Nations: Rome.

[14] IPCC, Impacts, adaptation and vulnerability: Contributions of Working Group II to the Fourth Assessment Report, Cambridge University Press, 2007, 444. Italiana 42:319-336 Italy, 2013.

[15] J.M. Rust, T. Rust, Climate change and livestock production: A review with emphasis on Africa. S. Afri. J. Anim. Sci. 43(3), 2013.

[16] J.T. Houghton, L.G. Meira Filho, B. Lim, K. Treanton, I. Mamaty, Y. Bonduki, D.J. Griggs, and B.A. Callender, (Eds). Revised 1996 IPCC Guidelines for National Greenhouse Gas Inventories, IPCC/OECD/IEA, 1997. available from http://www.ipccnggip.iges.or.jp/public /gl/ invs1 .htm, IPCC NGGIP, Japan.

[17] Journal of Animal Science, 86 (9), 2082 - 2088. Kebede, P.N. Bhat, A. da Silva Mariante, 2007. What's on the menu? Options for strengthening the lactating dairy cows in a subtropical environment? Journal of Dairy Science. 92, 109-116.

[18] linkages between biodiversity and climate change adaptation. A review of the recent scientific literature. UNEP World Conservation Monitoring Centre. livestock products with fair market access for the poor (Pro-Poor Livestock Policy Initiative London. management. Am. Dairy Sci. Assoc., Champaign, IL 61820, pp: 609-618.

[19] McManus C., Prescott E., Paludo G.R., Bianchini E., Louvandini H. \& Mariante A.S. (2008).

[20] Murray $N$ (2006) International trade and the spread of animal diseases: assessing the risks. Vet Italiana 42:319-336

[21] Pearson JE (2006) Worldwide risks of animal diseases: introduction. Vet Italiana 42:293

[22] Place, S.E.; Mitloehner, F.M. The nexus of environmental quality and livestock welfare. Annu. Rev. Anim. Biosci. 2014, 2, 555-569.

[23] Summary for policymakers. In Climate Change 2014: Impacts, Adaptation, and Vulnerability. Part A: Global and Sectoral Aspects.

[24] Thornton PK (2010) Livestock production: recent trends, future prospects. Philos Trans $R$ Soc B Biol Sci 365:2853-2867.warm climates. In: Van Horn, H.H.; Wilcox, C.J. (eds.).

[25] Zumbach, B., Misztal I. Tsuruta S., Sanchez J. P., Azain M., Herring W., Holl J., Long T., Culbertson $M$. 